\title{
Biostratigraphic Study of the Calcareous Nannofossils of Well 02, Shallow Offshore, Niger Delta, Nigeria
}

\author{
Alkali Y. Baba*, E.A. Okosun, Onoduku U. Shehu \\ Department of Geology, Federal University of Technology, Minna, Nigeria \\ *Corresponding Author: ybalkali@yahoo.com
}

Copyright (C) 2014 Horizon Research Publishing. All rights reserved.

\begin{abstract}
A calcareous nannofossils biostratigraphic study has been carried out on the strata penetrated of well 02 located in the shallow offshore area of the Niger Delta, Nigeria. The study is aimed at establishing the age and nannofossils biozonations of the well. The samples were prepared using smear slide technique. Forty calcareous nannofossils species were identified and used to make biostratigraphic deductions of zonations and dating of the sequence.The distribution of the calcareous nannofossils enabled the establishment of three zones of Helicosphaera ampliaperta (NN4),Sphenolithus heteromorphus (NN5) and Catinaster coalitus (NN8) belonging to early Miocene - late Miocene following standard zonation schemes of previous workers. The zones were based on the first and last occurrences of marker species. Nannofossil abundance / diversity patterns calibrated with chronostratigraphical bioevents reveals four condensed sections when correlated to the Global Cycle Chart. This is associated with the $16.0 \mathrm{Ma}$, 14.8 $\mathrm{Ma}$ and 13.4 $\mathrm{Ma}$ and 10.89 Ma maximum flooding surfaces.
\end{abstract}

Keywords Biotratigraphy, Biozonation, Nannofossils, Bioevents, Miocene

\section{Introduction}

This study focuses on the nannofossils Biostratigraphy of well-02, located on the shallow offshore portion of the Niger Delta. (Fig. 1) The aim of the study is to present biostratigraphic information from the nannofossils recovered from the strata penetrated.

Calcareous nannofossils are tiny (less than 30 microns) marine phytoplanktons. Tappan, 1980 considers the size of Nannoplankton to be less than $2 \mu \mathrm{m}$ and referred to those between size range of 2-20 $\mu \mathrm{m}$ as ultramicroplankton. They are classified as coccolith and nannolith, Perch- Nielsen, 1985. Coccoliths are disc-shaped plates, while the nannolith has various shapes including the star- shaped discoasters. They strive in normal marine environments and rarely tolerate turbidity and freshwater environment, Hay et al., 1967.

Calcareous nannofossils have been studied and reported in several literatures, but not much from the Niger Delta basin. This is attributed to the unpublished works of several nannofossils studies by oil companies who guard their information jealously.

Agagu,1981,Petters,1982,1983,Berggren,1960,Ozumba, 1995 and Okosun and Liebau,1999 recognized the Danian age for the sediment on the basis of Globorotalia pseudobulloides, Globigerina triloculinoides, Globigerinoides daubjergensis assemblages and assigned a lower Paleocene age to it. Adegoke et.al., 1976 presented a benthonic foraminifera biofacies of the delta. Orife and Avbovbo,1982 described the stratigraphic and unconformity traps of the Niger Delta,while Ogbe,1982 established the Paleoecology of the Western Niger Delta using foraminifera. He also identified those regressive phases on the basis of Microfauna and flora in the Niger delta.

The Niger Delta stratigraphic committee recently commissioned a biostratigraphic subcommittee mandated to carry out calcareous nannofossils taxonomic project as well as harmonize the various nannofossil schemes in use by different oil companies. The result of this project is yet to be made available for public use. Gallagher,1990,Farinaciari and Rio,1996 and Farinaciari et.al., 2000 presented quantitative stratigraphic studies on calcareous nannofossil of the Tertiary age.

Stradner, 1959 first reported the Discoasters of the Tertiary in Austria, the unpublished research works of Oyebamiji,1997,Fadiya,1999 and Akindipe,2003 comprise systematic calcareous nannofossils Biostratigraphic studies of some Niger Delta wells which were subdivided using the globally recognize zones of Martini and Bramlette,1963, Matini and Worsely,1970 and Matini,1971,Okada and Bukry,1980 and Berggren et.al 1995 Also Ojo et.al., 2009 studied nannofossils encountered from two deep offshore wells and subdivided into eight zones which were correlated.

However, this work is to identify the calcareous nannofossils encountered, establish the nanno zones in the analysed sequence and determine the age of the strata. 




Figure 1. Location map of well 02 shallow offshore Niger Delta, Nigeria

\section{Materials and Methods}

One hundred and twelve ditch cutting samples obtained at $30 \mathrm{ft}$ interval within the range of $6000-11000 \mathrm{ft}$ from well 02 located in the shallow offshore Niger Delta was utilized for this study. Samples collected at $30 \mathrm{ft}$ interval were to provide a high resolution biostratigraphic data. The well is code named well 02 for confidential reasons and the sample were provided by one of the multinational oil companies operating in the Niger Delta.

Smear slides method was employed for extracting nannofossils from the cuttings because; it is simple, rapid, cheap and efficient. About $4 \mathrm{~g}$ of the sample broken down by soaking and swirling in distilled water, then a small quantity of sodium hexametaphosphate ( calgon) is added to help disperse the sediment and ensure even distribution of the particles. A drop of this suspension is then placed on a glass cover slip followed by a drop of distilled water to dilute it and then dried on a hot plate at $60-70^{\circ} \mathrm{C}$ for few minutes and then mounted on a glass slides using a few drops of Norland optical adhesive mounting medium. This was then cured over ultraviolet light for 45 minutes. The prepared slides were examined for their calcareous nannofossil content using a light microscope under crossed polarizers and transmitted light at x 1000 magnification.

\section{Results}

Calcareous nannofossils recovery from this study is fairly abundant, diversified and moderately preserved (Fig. 2, Plates 1 and 2). One hundred and twelve samples from 6000 $11000 \mathrm{ft}$ of well 02 have been analysed for their calcareous nannofossil content. A total of 40 nannofossils species belonging to 17 genera were recognised. The nannofossils are mainly placoliths, nannoliths and helicoliths. Of these Helicosphaera carteri is the most abundant occurring throughout the entire analysed sequence. Sphenolithus heteromorphus also occur in abundance at the upper section of the studied interval and was used to define the upper section of the well. The family Noclacihabdacea represented by the genus Reticulofenestra has some of its species differentiated on the basis of size variation $R$. haqii (3-5 $\mu \mathrm{m})$, $R$. minuta $(<3 \mu m), R$. pseudoumbilicus $(>7 \mu \mathrm{m})$, Helicosphaerid coccoliths, represented by Helicosphaera carteri, Helicospheaera stalis, Helicosphaera obliqua, Helicosphaera deflandrei, Helicosphaera scissura and Helicosphaera ampliaperta which is a very important zonal index species of the lower section (NN4) of the studied well.
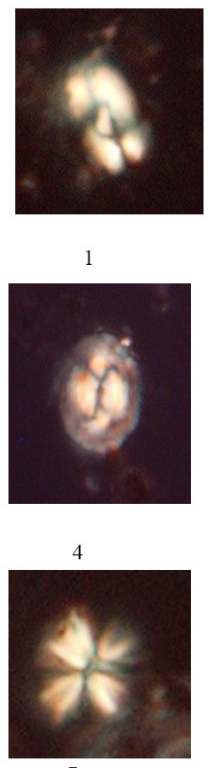
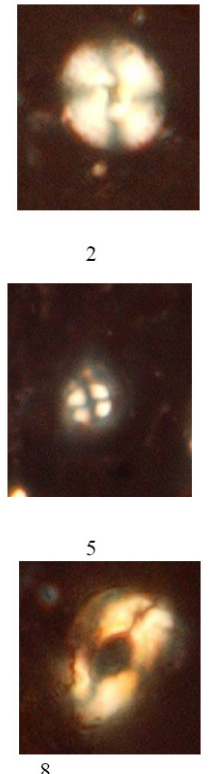

8

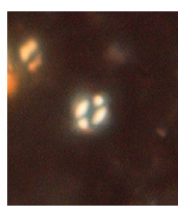

3
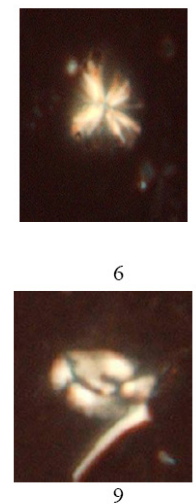

1 Braarudosphecra bigelowii (Gran and Braarud, 1935)

2 Coccolithus miopelagicus Deflandra, 1947, Bukry, 1971

3 Helicosphaera euphratis Haq, 1966

4-5 Sphenolithus heteromorphus Deflandre, 1953

6 Discoaster deflandrei Bramlette and Riedel, 1954

7 Discoaster sanmiguelensis, Bukry, 1981

Plate 1. (Calcareous Nannofossils) 

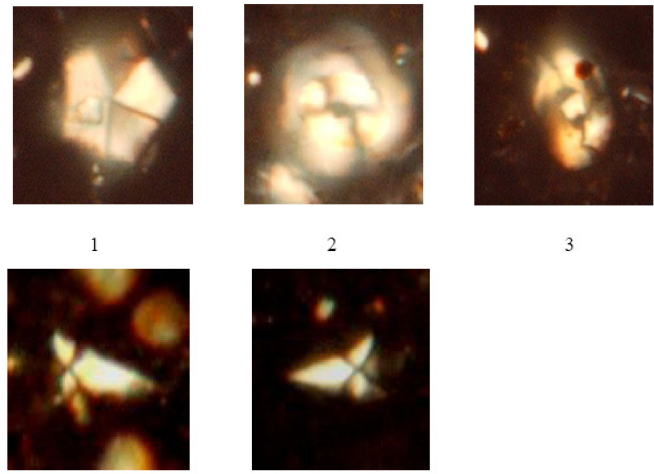

2
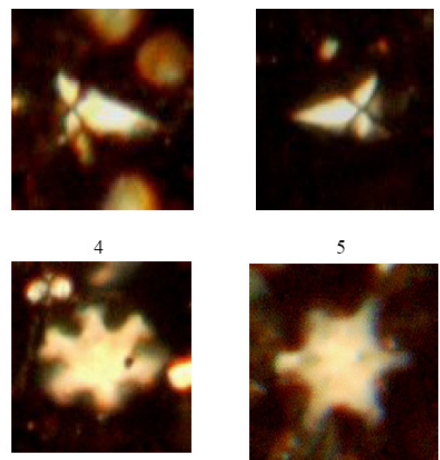

6

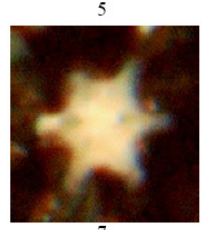

1 Helicosphaera intermedia Martini, 1965

2 Cyclicargolithus floridanus Roth and Hay in Hay et al,1967, Bukry,1971a 3-5 Coccolithus pelagicus Schiller, 1930

6 Sphenolithus dissimilis Bukry and Percival, 1971

7 Sphenolithus moriformis Bronnimann and Stradner,1960, Bramlette Wilcoxon, 1967

8 Helicosphaera ampliaperta, Bramlette \& Wilcoxon, 1967

9 Helicosphaera obliqua, Bramlette \& Wilcoxon , 1967

Plate 2. (Calcareous Nannofossils

Three major zones were delineated for the interval $(6000$ $-11000 \mathrm{ft}$ ) of well 02 , based on the first and last occurence of marker species. The zones are; Helicosphaera ampliaperta, Sphenolithus heteromorphus and Catinaster coalitus. (Table 1)

\subsubsection{Heliscosphaera ampliaperta Zone}

Stratigraphic interval: $8330-11000 \mathrm{ft}$

Age- early Miocene

Definition: The top of this zone is recognised in the well and is placed as the first down hole occurrence (FDO) of Helicosphaera ampliaperta at $8330 \mathrm{ft}$. The base was not seen but has been placed at the base of the studied interval. The zone is also characterised by the top occurrence of Sphenolithus dissimilis and base occurrence of Helicosphaera intermedia. The zone corresponds to the NN4 zone of Martini,1971 and the CN 3 of Okada and Bukry,1980.

\subsubsection{Sphenolithus heteromorphus Zone}

Stratigraphic interval: $7370-8330 \mathrm{ft}$

Age- middle Miocene

Definition: The zone is defined by the top of Sphenolithus heteromorphus at the $7970 \mathrm{ft}$ and the top of $H$. ampliaperta as the base at $8330 \mathrm{ft}$. The zone is also characterised by the LDO of $\mathrm{H}$. intermedia and $H$. obliqua. The zone is equivalent to the NN5 of Martini, 1971 and Okada and Bukry, 1980.

\subsubsection{Catinaster coalitus Zone}

Stratigraphic interval: $6040-7370 \mathrm{ft}$

Age: late Miocene

Definition: The zone lies between the base of the Catinaster coalitus at $7370 \mathrm{ft}$ and the top of the intervals. The zone is also characterised by FDO's of Sphenolithus moriformis and Calcidiscus leptoporus and LDO's of Discoaster bollii The zone has been correlated to NN8 of Martini,1971 and CN7 of Okada and Bukry,1980.

Table I. Calcareous Nannofossils Zonation Recognised in Well 02

\begin{tabular}{|c|c|c|c|c|c|c|}
\hline $\begin{array}{l}\text { Depth } \\
\text { (ft) }\end{array}$ & $\begin{array}{l}\text { Epoch/ } \\
\text { Period }\end{array}$ & $\begin{array}{l}\text { Hardenbol et. al., } \\
\text { (1998) Scheme }\end{array}$ & Martini (1971) & $\begin{array}{c}\text { Okada and } \\
\text { Bukry, } 1975 \text {, } \\
1980\end{array}$ & This study & Bioevents \\
\hline 6010 & \multirow{2}{*}{ 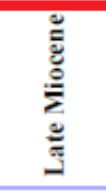 } & \multirow{4}{*}{$\begin{array}{l}10.89 \mathrm{Ma} \\
13.4 \mathrm{Ma}\end{array}$} & \multirow[t]{2}{*}{ NN8 } & \multirow[t]{2}{*}{ CN6 } & \multirow[t]{2}{*}{ 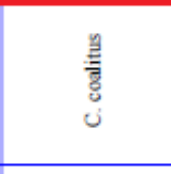 } & $\begin{array}{c}6100 \text { FDO Calcidiscus leptoponis } \\
\text { FDO Catinaster coalitus } \\
7040 \text { LDO Discoaster bolli }\end{array}$ \\
\hline \multirow[t]{2}{*}{7000} & & & & & & $\leftarrow$ 7370-LDO Catinaster coalitus \\
\hline & \multirow{2}{*}{ 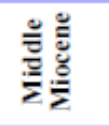 } & & $\begin{array}{l}\text { NN6 - NN7 } \\
7970\end{array}$ & $\mathrm{CN} 5$ & \multirow[t]{2}{*}{ S. heteromorphus } & Base - Coronocyclus nitescens \\
\hline 8000 & & & NN5 & $\mathrm{CN} 4$ & & $\leftleftarrows$ 8180-LDO Helicosphaera obliqua \\
\hline & \multirow{3}{*}{ 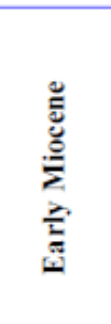 } & \multirow{3}{*}{$\begin{array}{l}8450 \\
14.8 \mathrm{Ma} \\
9290\end{array}$} & \multirow{3}{*}{ NN4 } & \multirow{3}{*}{$\mathrm{CN} 3$} & \multirow{3}{*}{ 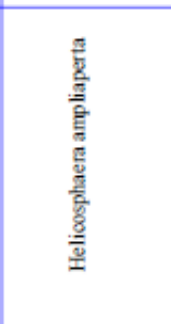 } & $\begin{array}{l}\text { 8330-FDO Helicosphaera } \\
\text { ampliaperta }\end{array}$ \\
\hline 9000 & & & & & & $\leftarrow 9290$ FDO Discoaster deflandrei \\
\hline $\begin{array}{l}10000 \\
10500\end{array}$ & & & & & & $\begin{array}{l}\leftarrow 10310 \text { FDO Sphenolithus dissimilis } \\
\leftarrow 10550 \text { LDO Coalitus pelagicus }\end{array}$ \\
\hline
\end{tabular}




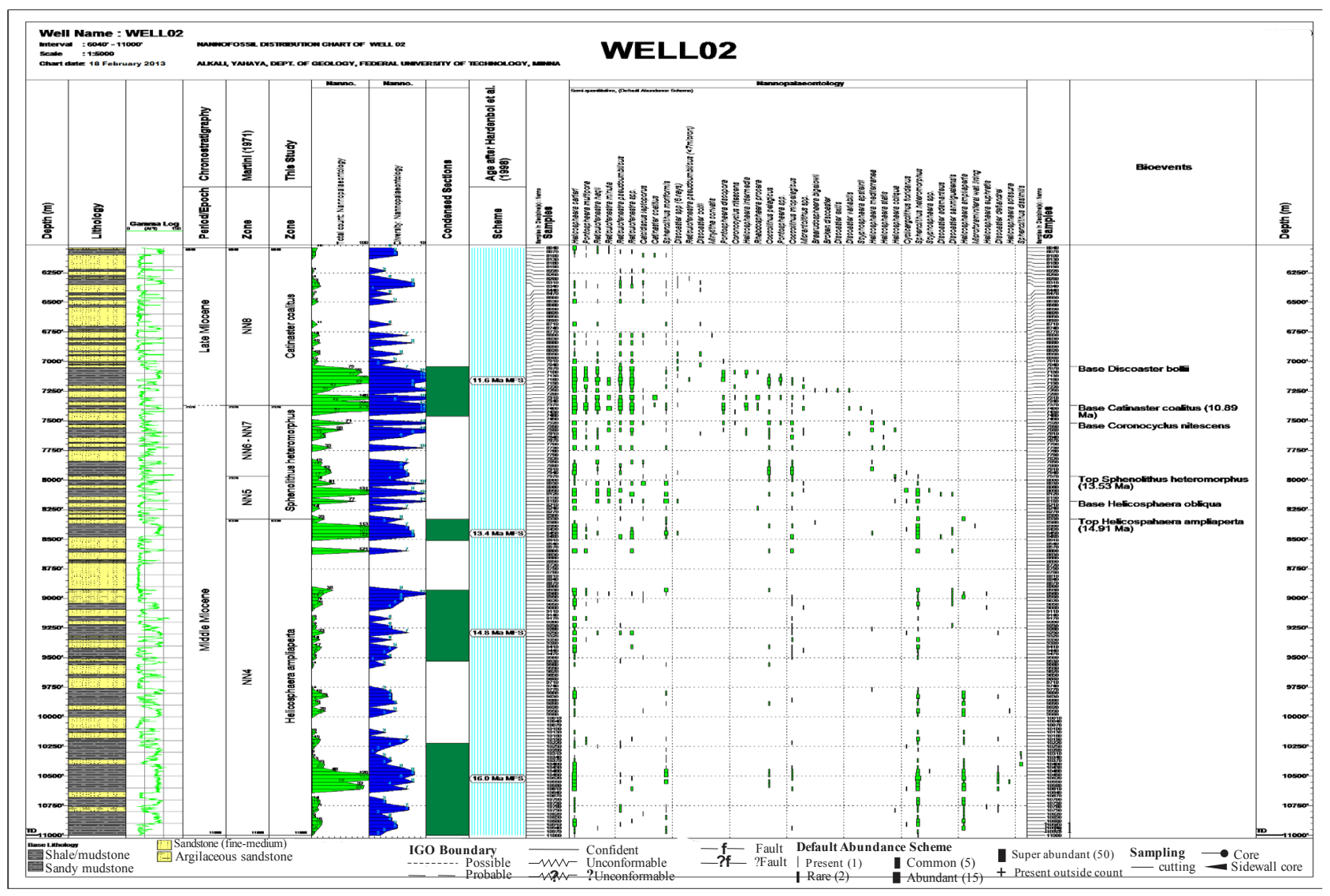

Figure 2. Nannofossil Distribution Chart of Well 02, Shallow Offshore, Niger Delta3.1 Biozonations

\section{Conclusion}

The investigated interval of well 02 showed fairly abundant, diversified and well preserved calcareous nannofossil assemblage. The distribution pattern of the biostratigraphically significant nannofossil markers within the studied interval $(6000 \mathrm{ft}-11000 \mathrm{ft})$ has been studied using first and last occurrences of marker species and assemblage characteristics.

Nannofossils recovered from the cuttings were mainly placolith, nannoliths and helicoliths. Based on the distribution and occurrences of marker species, three nannofossil zones were establish: Helicosphaera ampliaperta (NN4/CN3), Sphenolithus heteromorphus (NN5/CN4) and Catinaster coalitus (NN6/CN5). The zones have been assigned early Miocene to late Miocene following the Zonation of Martini ( 1971) and Okada and Bukry (1980).

\section{Acknowledgements}

The authors wish to sincerely express their gratitude to Crystal Age Ltd, Lagos, Nigeria for making their facilities available for this study

\section{REFERENCES}

[1] H. TAPPAN, Haptophyta, Coccolithophores and other calcareous nannoplankton. The Paleobiology of Plant Protista. Freeman San Francisco, 678-803, 1980.

[2] K. Perch-Nielsen, Cenozoic calcareous nannofossil, in Bolli, H.M., J.B. Saunders, and K. Perch-Nielsen, (Eds.), Plankton Stratigraphy, Cambridge Earth Sciences Series, Cambridge University Press: p. 427-554,1985.

[3] O.K. Agagu, Effect of overpressure in petroleum accumulation in the Niger Delta subsurface. American Association of Petroleum Geologists Bulletin, United States of America,70: pp. 50-75, 1981.

[4] S.W. Petters, , Central West African Cretaceous -Tertiary benthic foraminifera and stratigraphy. Palaeontographica Abt. A., 179: pp 1-104, 1982.

[5] S.W. Petters, Some late Tertiary foraminifera from Parabe-1, western Niger Delta Rev.Esp. Microbial,11 pp 119-133,1984.

[6] W.A. Berggren, Rates of evolution of some Cenozoic planktonic foraminifera. Micropalaeontology, 15(3): pp 351-365,1960.

[7] M.B.Ozumba, Late Miocene-Pliocene Biostratigraphy offshore Niger Delta. Nigerian Association of Petroleum Explorations Bulletin 12(01): pp46-53, 1995.

[8] E.A. Okosun, and A. Liebau, Late Palaeocene biostratigraphy and palaeoecology of Sokoto basin,North western Nigerian 
Journal of minerals and Geology, 35(2): pp 153, 1999.

[9] O. S. Adegoke,M. E. Omatsola and M. B. Salami,Benthonic foraminiferal biofacies of the Niger Delta.1st Intern. Symp. On benthonic foraminiferal. Maritime Sediments, Spect. Publ. 1, pp. $272-292,1976$

[10] M. Orife, and A. A. Avbovbo, Stratigraphic and unconformity traps in the Niger Delta. AAPG Bull., in: the search for subtle oil traps, AAPG Memoir 32, pp. 251-265. 1982

[11] F.G.A. Ogbe, The biostratigarphy of the Niger Delta,Nigeria. Journal of Mining and Geology, 18(2): pp 545-582. 1982.

[12] L.T. Gallagher, Calcareous nannofossils biozonation of the Tertiary of the North Sea basin. Newsletters on Stratigraphy, 22: pp 21-44. 1990.

[13] E. Farinaciari and D. Rio,Latest Oligocene to early middle Miocene quantitative calcareous nannofossils Biostratigraphy in the Mediterranean region. Journal of Micropalaeontology, 42: pp 1-37. 1996.

[14] E. S.Farinaciari, A.D. Rio, D. and A. Negri,, Middle Miocene quantitative calcareous nannofossils biostratigraphy in the Mediterranean region. Journal of Micropalaeontology, 42:pp $38-64,2000$

[15] H. Stradner, First report on the Discoasters of the tertiary of Austria and their stratigraphic use. Proceedings of the 5th World Petroleum Congress, 1: pp 1081-1095 1959

[16] S.A Oyebamiji, Calcareous nannofossils biostratigraphy of a well in the Niger Delta,Nigeria. Unpublished M.Sc.thesis, University College, London, 83p. 1997.

[17] S.L.Fadiya, Foraminifera and calcareous nannofossils biostratigraphy and well-log sequence Stratigraphic analysis of Opolo-5 and Opolo-6 wells, Niger Delta. Unpublished M.Sc.thesis, Department of Geology,Obafemi Awolowo University, Ile-Ife. 149p Abstract published- American Association of PetroleumGeologists Bulletin, 82(11): pp 2162, 1999.

[18] A. O.Akindipe,Calcareous nannofossil Biostratigraphy of well XX, Niger Delta,Unpub.B.Sc. Thesis, Department of Geology, Obafemi Awolowo University, Ile-Ife, 52p, 2003.

[19] E. Martini, and M.N. Bramlette, Calcareous nannoplankton from the experimental Mohole drilling. Journal of Palaeontology, 37: pp 845-855, 1963.

[20] E. Martini, and T., Worsely, Standard Neogene calcareous nannoplankton zonation.Nature, 225: pp 289-290,1970.

[21] E. Martini, Standard Tertiary and Quaternary calcareous nannoplankton zonation. In:Farinacci (eds),ProceedingsII planktonic conference, Roma, 1970, 2: pp 739-785, 1971..

[22] H. Okada,and D.Bukry,Supplementary modification and introduction of code numbers to low latitude coccoliths biostratigraphic zonation. Marine micropalaeontology, Netherlands,5(2): pp 321-325,1980.

[23] W.A. Berggren, D.V. Kent, C.C. Swisher, and M., Aubry,A revised Cenozoic Geohronology and Chronstratigraphy. In: Geochronology Time Scales and Global Stratigraphic Correlation, Society of Economic Palaeontologists and Mineralogists specialpublication, 54:pp 129-211,1995.

[24] E. A Ojo, L. S. Fadiya and O. A. Ehinola, Biozonation and correlation of BDX-1 and BDX-2 wells of deep offshore Niger Delta using calcareous nannofossils. Search and Discovery Article (AAPG), no. 50194, 8 pp. 2009. 